\title{
THE EFFECT OF EXTRACTION CONDITION ON THE POLYPHENOL CONTENT AND ANTIOXIDANT ACTIVITY OF Curcuma zedoaria (Christm.) ROSCOE RHIZOME
}

\author{
Lia Marliani, Wempi Budiana, dan Yonara Anandari \\ Sekolah Tinggi Farmasi Bandung, Bandung, Indonesia
}

\begin{abstract}
ABSTRAK
White turmeric (Curcuma zedoaria (Christm.) Roscoe) is one of Indonesian herbal medicine. The extraction process to get polyphenol compound from natural product was influenced by some factor such as solvent, temperature, time, and method of extraction. The objective of this study was to determine the significant factor of extraction that is solvent, temperature and time of extraction on the polyphenol content and antioxidant activity of white turmeric (Curcuma zedoaria (Christm.) Roscoe) rhizome. Extraction was done by dynamic maceration method with variations $\left(2^{3}\right.$ factor variable design) of solvent (ethanol $96 \%$ and water), temperature $\left(25^{\circ} \mathrm{C}\right.$ and $\left.70^{\circ} \mathrm{C}\right)$, time (6 and 24 hours). The method of analysis of polyphenol content using Folin Ciocalteu reagent, and the antioxidant activity using DPPH free radical reduction method. The experiment design and data analysis using Design-Expert ${ }^{\circledR}$ Software Version 10. The result showed that extraction using ethanol $96 \%$ at $70^{\circ} \mathrm{C}$ for 24 hours was gave high polyphenol content and antioxidant activity. Data analysis was showed that polyphenol content and antioxidant activity was influenced only by solvent of extraction. This study indicated that solvent is significant extraction factor for polyphenol content and antioxidant activity of white turmeric (Curcuma zedoaria (Christm.) Roscoe) rhizome.
\end{abstract}

Keywords: Antioxidant, Curcuma zedoaria (Christm.) Roscoe, extraction, polyphenol

\section{Pengaruh Kondisi Ekstraksi terhadap Kandungan Polifenol dan Aktivitas Antioksidan Rimpang Curcuma zedoaria (Christm.) Roscoe}

\begin{abstract}
Temu Putih (Curcuma zedoaria (Christm.) Roscoe) adalah salah satu obat herbal Indonesia. Proses ekstraksi untuk mendapatkan senyawa golongan polifenol dipengaruhi oleh beberapa factor seperti pelarut, suhu, waktu, dan metode ekstraksi. Tujuan penelitian ini adalah untuk menentukan faktor ekstraksi (pelarut, suhu, dan waktu ekstraksi) yang signifikan terhadap kandungan polifenol dan aktivitas antioksidan dari rimpang temu putih (Curcuma zedoaria (Christm.) Roscoe) rhizome. Ekstraksi dilakukan dengan metode maserasi dinamik dengan variasi (variasi desain faktorial $2^{3}$ ) pelarut (etanol $96 \%$ dan air), suhu $\left(25^{\circ} \mathrm{C}\right.$ and $70^{\circ} \mathrm{C}$ ), waktu (6 dan 24 jam). Penetapan kadar polifenol menggunakan reagen Folin Ciocalteu dan aktivitas antioksidan menggunakan metode reduksi radikal bebas DPPH. Design eksperimen dan analisis data menggunakan Software Design-Expert ${ }^{\circledR}$ Version 10. Hasil penelitian menunjukkan bahwa ekstraksi menggunakan ethanol $96 \%$ pada suhu $70^{\circ} \mathrm{C}$ selama 24 menghasilkan kandungan poliphenol dan aktivitas antioksidan tertinggi. Analisis Data menunjukkan bahwa kandungan Polifenol dan aktivitas antioksidan hanya dipengaruhi oleh pelarut ekstraksi. Penelitian ini menunjukkan bahwa pelarut merupakan faktor ekstraksi yang signifikan terhadap kandungan polifenol dan aktivitas antioksidan rimpang Temu Putih (Curcuma zedoaria (Christm.) Roscoe).
\end{abstract}

Kata kunci : Antioksidan, Curcuma zedoaria (Christm.) Roscoe, ekstraksi, polifenol 


\section{Introduction}

White turmeric (Curcuma zedoaria (Christm.) Roscoe) is one of family Zingiberaceae that usually used as one of Indonesian herbal medicine. Its rhizome has antioxidant, anti-inflammatory, anticancer and anti-microbial activity ${ }^{1}$. White turmeric contains bioactive compounds such as flavonoids, polyphenols, curcuminoid, terpenoids and essential oils. There are approximately 60 essential oil components and oleoresin in white turmeric with curzerenone, germacrone, camphor, curcumenol as the largest component ${ }^{2}$.

The one of antioxidant compound of white turmeric is polyphenols. Polyphenols has been known as potent antioxidant. Polyphenols can scavenge radical species or inhibit some enzymes or chelating trace metals which involve in free radical formation ${ }^{3}$.

The extraction process aims to obtain maximum active compounds and the best quality in activities. The yield of extraction is influenced by the type of extraction method, solvent, extraction time, and temperature ${ }^{4,5,6}$. There is no universal extraction method for all phenolic compounds because their solubility and physical characteristics varying as well as varying form of phenolic compounds from simple to highly polymerized substances ${ }^{3}$. Total phenol content and total flavonoid content of the extract are varying depend on extraction solvent ${ }^{7}$. The higher amounts of phenolic compound often extracted by more polar organic solvent such as methanol and ethanol. The amount of polyphenols extracted are influenced by selecting the right solvent ${ }^{8}$. According to Wissam et al, $2012^{9}$, an increasing temperature of extraction will increases the extraction efficiency by increases cell permeable, solubility and diffusion coefficients of the compounds.

The antioxidant activities are depending on the level of antioxidant compound was extracted. The purpose of this study was to determine the significant

extraction factors that influence the polyphenol content and antioxidant activity of white turmeric (Curcuma zedoaria (Christm.) Roscoe).

\section{Materials and Methods \\ Materials}

White turmeric (Curcuma zedoaria (Christm.) Roscoe) rhizome were collected from Purwakarta, West Java, Indonesia, at Februari 2016. The specimen were identified at Herbarium Biology Department, Padjadjaran University, Bandung, Indonesia. Sample was dried by oven at temperature $50^{\circ} \mathrm{C}$ for 2 days. Dry material grinded and was sieved by mesh 20 sieve.

\section{Extraction}

Sample was extracted by dynamic maceration method using $2^{3}$ variable factor (two levels of three factor) includes variation of solvent (ethanol $96 \%$ and water) in $200 \mathrm{~mL}$, temperature $\left(25^{\circ} \mathrm{C}\right.$ and $70^{\circ} \mathrm{C}$ ) and time (6 hours and 24 hours). The extraction process was done in an orbital shaker at stirring speed of $30 \mathrm{rpm}$. Each extract was concentrated using Buchi ${ }^{\circledR}$ Rotavapor $^{\circledR}$ R-215 to obtain spissum extract.

\section{Determination of total phenol content}

Total phenolic compounds contents were determined by the Folin-Ciocalteau method ${ }^{10}$. The $0.5 \mathrm{ml}$ extract samples were mixed with $5 \mathrm{ml}$ Folin Ciocalteu reagent for 5 minute and $\mathrm{Na}_{2} \mathrm{CO}_{3}(4 \mathrm{ml}, 1 \mathrm{M})$ then added. The mixture was allowed to stand for $15 \mathrm{~min}$ and the phenols were determined by colorimetry at $765 \mathrm{~nm}$. The standard was $20,40,50,60,80$, and $100 \mu \mathrm{g} / \mathrm{ml}$ gallic acid. Total phenol values are expressed in terms of gallic acid equivalent $(\mu \mathrm{g} / \mathrm{ml}$ of dry mass), which is a common reference compound

$$
\text { Total phenol content }\left(\frac{m g}{G}\right)=\frac{\text { Gallic acid equvalent }\left(\frac{\mu \mathrm{g}}{\mathrm{ml}}\right) \cdot 10^{-3}}{\text { Sample concentration }\left(\frac{\mu \mathrm{g}}{\mathrm{ml}}\right) \cdot 10^{-6}}
$$




\section{Determination of antioxidant activity}

The free radical scavenging activity of extract was determined using the stable radical DPPH (1,1-diphenyl-2picrylhydrazyl) $\quad 10,11$ Different concentration of each extract (50-250 $\mu \mathrm{g} / \mathrm{ml}$ for ethanol $96 \%$ extract and 500$1000 \mu \mathrm{g} / \mathrm{ml}$ for water extract) were added at equal volume (1:1) of freshly prepared DPPH solution $(60 \mu \mathrm{g} / \mathrm{ml})$ in methanol in each test tube and mixed. The absorbance was measured after 30 min incubation at $516 \mathrm{~nm}$ ( $\lambda_{\max }$ of DPPH solution). The capability to scavenge the DPPH radical was calculated using the following equation:

$\mathrm{DPPH}$ scavenged $(\%)=[(\mathrm{Ac}-$ As)/Ac] 100

Ac is the absorbance of the control (DPPH solution) and As is the absorbance of the extracts. The antioxidant activity of the extract was expressed as IC50. The IC50 value was determined from linear regression analysis with Concentrations of extract as $\mathrm{X}$ axis and DPPH scavenged (\%) as $\mathrm{Y}$ axis.

\section{Data analysis}

The results were analyzed by Factorial analysis. ANOVA/ Response Surface Methodology (RSM) on the experimental data was performed using using Design-Expert ${ }^{\circledR}$ Software Version 10 to determine which factors of solvent, temperature and time that influence the total phenols content, and antioxidant activity.

The mathematical models for each response were evaluated using a multiple regression method. The response function applied was a linear polynomial equation, given by equation (1):

$$
Y=\beta_{0}+\sum_{i=1}^{k} \beta_{i} x_{i}+\sum \beta_{i j} x_{i} x_{j}
$$

In equation (1), $\mathrm{Y}$ is the dependent variable; $\beta_{0}$ is the constant term; $\mathrm{k}$ number of variables; $\beta i$ represents the coefficients of linear parameters; $\beta \mathrm{ij}$ represents the coefficients of interaction parameters.

The significance of the equation parameters for each response variable was analyzed by F-test. Only the factors with significance higher than or equal to $5 \%$ $(p \leq 0.05)$ were considered. The model adequacy was checked accounting for the coefficient of determination $\left(\mathrm{R}^{2}\right)$. The response and result of data analysis by Design-Expert ${ }^{\circledR}$ Software Version 10 was showed by Interaction plot graphic (2D).

\section{Results and Discussion}

The result of total phenol content determination showed that the highest content was obtained by extraction using ethanol $96 \%$ at 24 hours and temperature $70^{\circ} \mathrm{C}$ (see Table 1 ).

Table 1 Yield and Total Phenol Content of Extract

\begin{tabular}{|c|c|c|c|c|}
\hline \multicolumn{3}{|c|}{ Extraction factor variation } & \multirow[b]{2}{*}{ Yield (\%) } & \multirow{2}{*}{$\begin{array}{c}\text { Total Phenol } \\
\text { Content } \\
\text { (mgGAE/G) }\end{array}$} \\
\hline Solvent & $\begin{array}{c}\text { Temperature } \\
\left({ }^{\circ} \mathrm{C}\right)\end{array}$ & $\begin{array}{c}\text { Time } \\
\text { (hours) }\end{array}$ & & \\
\hline Water & 25 & 6 & $29.40 \pm 0.990$ & $20.869 \pm 3.648$ \\
\hline Water & 25 & 24 & $28.75 \pm 1.060$ & $20.376 \pm 2.079$ \\
\hline Water & 70 & 6 & $31.95 \pm 2.758$ & $19.945 \pm 6.831$ \\
\hline Water & 70 & 24 & $26.08 \pm 0.813$ & $23.463 \pm 2.010$ \\
\hline Ethanol $96 \%$ & 25 & 6 & $18.70 \pm 0.778$ & $76.879 \pm 2.803$ \\
\hline Ethanol $96 \%$ & 25 & 24 & $18.05 \pm 0.848$ & $84.028 \pm 3.834$ \\
\hline Ethanol $96 \%$ & 70 & 6 & $23.70 \pm 2.616$ & $80.250 \pm 5.821$ \\
\hline Ethanol $96 \%$ & 70 & 24 & $26.15 \pm 5.162$ & $84.150 \pm 4.142$ \\
\hline
\end{tabular}


This is accordance with Do et al. research ${ }^{7}$ which its result showed the extract obtained by $100 \%$ ethanol has highest phenolic content than other solvent and the water extract showed the lowest phenolic content. Rhizome may contain varying phenolic compounds from simple to polymerized subtances. The other compound such as carbohydrates and proteins may also associated with phenolics compound $^{3}$. The complex polyphenols are more soluble in organic solvent, such as ethanol than water. The solubility of nonphenol compounds like carbohydrate and protein are higher in water than in ethanol ${ }^{12}$. The water can extract other compound of white turmeric such as amylum that also abundant in rhizome. This maybe the reason why ethanol $96 \%$ extract gave the highest the total phenol content.

Temperature and extraction time are enhancing the solubility and diffusion coefficient of solute ${ }^{13}$. The result showed that at $70^{\circ} \mathrm{C}$ and 24 hour extraction, both water and ethanol extract gave the highest phenolic compound. The chance of denaturation and oxidation of phenolics is increased by high temperature and long extraction which decrease the yield of phenolics in the extracts ${ }^{7}$. The result showed that at $70^{\circ} \mathrm{C}$ and 24 hour extraction, phenolic compound of white turmeric (Curcuma zedoaria (Christm.) Roscoe) rhizome may not be denaturated or oxidized.

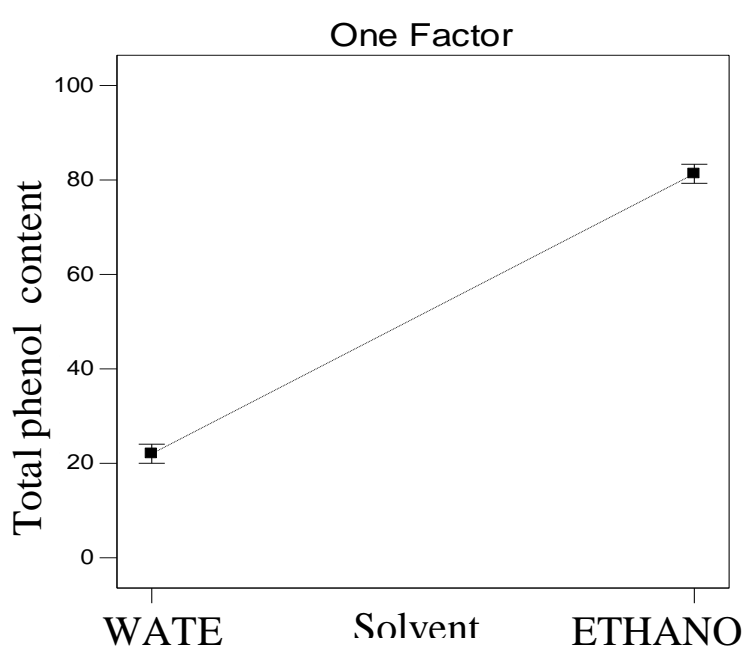

Figure.1 : The graphic of solvent effect to total phenol content (Design-Expert ${ }^{\circledR}$ )

Although at different temperature and time of extraction showed different phenol content, the data analysis by Design-Expert ${ }^{\circledR}$ showed only solvent variation ((significance higher than $5 \%, \mathrm{p}$ $\mathrm{p} \leq 0.05)$ could affecting the total phenol content and ethanol 96\% gave the highest total phenol content (figure 1).

The result of antioxidant activity that determined by free radical DPPH scavenging activity showed the lowest $\mathrm{IC}_{50}$ value also was obtained by extraction using ethanol $96 \%$ at 6 hours and temperature $70^{\circ} \mathrm{C}$ (see Table 2 ). 
Table 2 : IC 50 value of Extract

\begin{tabular}{|c|c|c|c|}
\hline \multicolumn{3}{|c|}{ Extraction factor variation } & \multirow[b]{2}{*}{$\operatorname{IC50}(\mu \mathrm{g} / \mathrm{ml})$} \\
\hline Solvent & $\begin{array}{c}\text { Temperature } \\
\left({ }^{\circ} \mathrm{C}\right)\end{array}$ & $\begin{array}{c}\text { Time } \\
\text { (hours) }\end{array}$ & \\
\hline Water & 25 & 6 & $956.16 \pm 20.27$ \\
\hline Water & 25 & 24 & $754.80 \pm 244.38$ \\
\hline Water & 70 & 6 & $821.18 \pm 107.20$ \\
\hline Water & 70 & 24 & $756.13 \pm 77.83$ \\
\hline Ethanol 96\% & 25 & 6 & $203.12 \pm 9.69$ \\
\hline Ethanol 96\% & 25 & 24 & $194.70 \pm 0.40$ \\
\hline Ethanol 96\% & 70 & 6 & $184.25 \pm 6.35$ \\
\hline Ethanol $96 \%$ & 70 & 24 & $210.12 \pm 5.13$ \\
\hline
\end{tabular}

The lowest $\mathrm{IC}_{50}$ value determine the more potent antioxidant activity. This result (Table 1 and 2) showed that the high total phenol content gave the most active antioxidant. It is also determined the role of polyphenol as antioxidant compound of white turmeric (Curcuma zedoaria (Christm.) Roscoe). Although at different temperature and time of extraction showed different phenol content, but they are not significant.
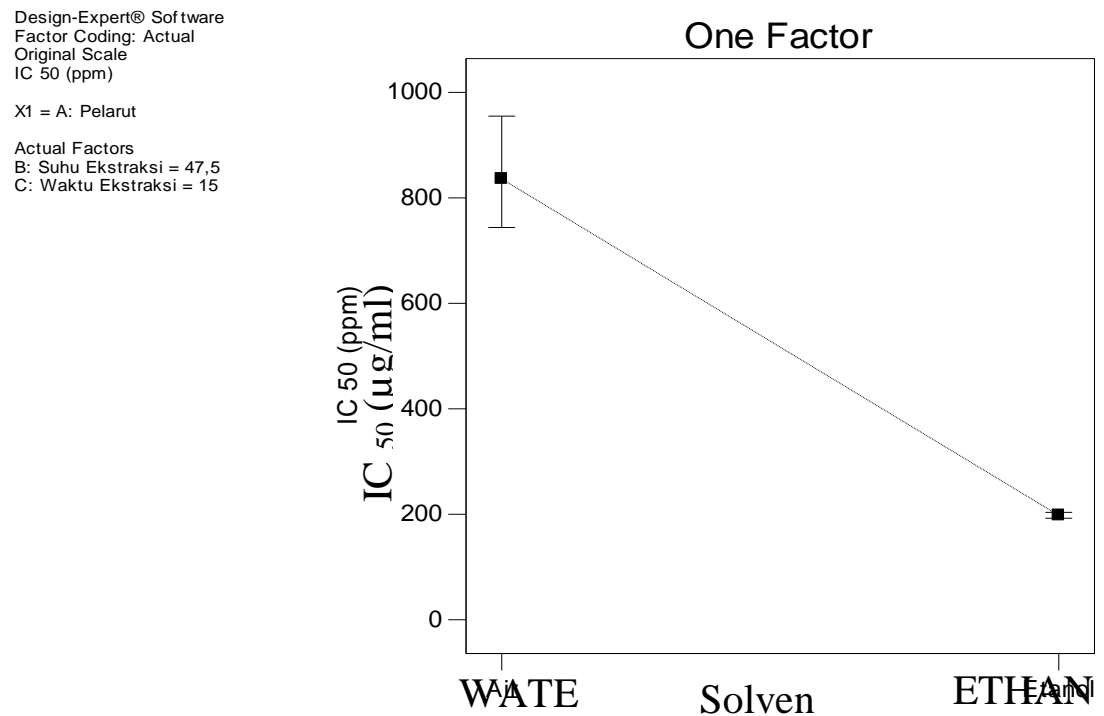

Figure. 2 : The graphic of solvent effect $: \mathrm{P}_{\mathrm{el}} \mathrm{If}_{\mathrm{f}} \mathrm{f} 0$ value (Design-Expert $($ ) 
The data analysis by DesignExpert ${ }^{\circledR}$ determines that only solvent variation (significance higher than 5\%, $\mathrm{p} \leq 0.05$ ) could influence the antioxidant activity (figure 2). The potent antioxidant showed by extract which obtain using organic solvent (ethanol 96\%).

\section{Conclusion}

This study showed that solvent is significant extraction factor for polyphenol content and antioxidant activity of white turmeric (Curcuma zedoaria (Christm.) Roscoe) rhizome than temperature and time of extraction.

\section{Acknowledgement}

This research was supported by an Internal Grant from Bandung School of Pharmacy, Bandung, Indonesia.

\section{References}

1. Lobo R, Prabhu KS, Shirwaikar A, Shirwaikar A. Curcuma zedoaria Rosc. (white turmeric): a review of its chemical, pharmacological and ethnomedicinal properties. Journal of Pharmacy and Pharmacology. 2009; 61: 13-21.

2. Singh $\mathrm{P}$, Singh $\mathrm{S}$, Kapoor IPS, Singh G, Isidorov, V, Szczepaniak L. Chemical composition and antioxidant activities of essential oil and oleoresins from Curcuma zedoaria rhizomes, part-74. Food Bioscience. 2013; 3: 42-48

3. Dai J, Mumper RJ. Plant Phenolics: Extraction, Analysis and Their Antioxidant and Anticancer Properties. Molecules. 2010,15:7313-7352

4. Spigno G, Tramelli L, Faveri D.M.D. Effects of extraction time, temperature and solvent on concentration and antioxidant activity of grape marc phenolics. Journal of Food Engineering. 2007; 81: 200-208.

5. Chew K.K, Ng S.Y, Thoo Y.Y, Khoo M.Z., Wan Aida W.M, Ho C.W. Effect of ethanol concentration, extraction time and extraction temperature on the recovery of phenolic compounds and antioxidant capacity of Orthosiphon stamineus extracts. International Food Research Journal. 2011; 18: 1427-1435.

6. Ng L.Y., Ang Y.K., Khoo H.E. and Yim H.S. Influence of different extraction parameters on antioxidant properties of Carica papaya peel and seed. Research Journal of Phytochemistry. 2012; 6: 61-74.

7. Do QD, Angkawijaya AE, TranNguyen PL, Huynh LH, Soetaredjo FE, Ismadji S, Ju YH. Effect of extraction solvent on total phenol content, total flavonoid content, and antioxidant activity of Limnophila aromatic. Journal of Food and Drug Analysis. 2014; 22: 296-302

8. Xu B.J., Chang S.K. A. comparative study on phenolic profiles and antioxidant activities of legumes as affected by extraction solvents. Journal of Food Scince. 2007; 72: S159-166.

9. Wissam Z., Bashour Ghada B., Wassim A., Warid K. Effective extraction of polyphenols and proanthocyanidins from pomegranate's peel. International Journal of Pharmacy and Pharmaceutical Sciences. 2012; 4(3): 675 - 682.

10. Ghasemi K, Ghasemi Y, Ebrahimzadeh MA. Antioxidant Activity, Phenol and Flavonoid Contents of 13 Citrus Species Peels and Tissues. Journal and Pharmaceutical Sciences. 2009; 22(3): 277-281

11. Seal T. Evaluation of antioxidant activity of some wild edible fruits of Meghalaya state in India. International Journal of Pharmacy and Pharmaceutical Sciences. 2011; 3(4):233-236

12. Sultana B, Anwar F, Ashraf M. Effect of Extraction 
Solvent/Technique on the Antioxidant Activity of Selected Medicinal Plant Extracts.

Molecules. 2009; 14 : 2167-2180

13. Spigno G., and De Faveri D. M. Antioxidants from grape stalks and marc: influence of extraction procedure on yield, purity and antioxidant power of the extracts. Journal of Food Engineering. 2007; 8:793-801. 